\title{
The Model of Management Quality for Islamic Higher Education: A Case Study at the STIT Al Hikmah Tebing Tinggi
}

\author{
Hasan Asari, Neliwati, \& Ahmad Ibrahim Hasibuan* \\ Universitas Islam Negeri Sumatera Utara, Medan, Indonesia \\ *Corresponding Author: ahmadibrahimhsb@gmail.com
}

\begin{abstract}
This study aims to analyze the quality management of Islamic higher education at STIT Al Hikmah Tebing Tinggi. The research method used in this research is qualitative research with a phenomenological approach. Based on the results of the study, it was found that planning activities included the activities of the tri dharma tertiary programs, both the development of the vision and mission or the programs carried out based on the results of the evaluation. Meanwhile, the implementation activities include detailing the budget needed to improve the quality of education in the implementation of all forms of academic process activities. The implementation of all work programs that have been arranged according to the time schedule in the semester time period, then compile the details of the needs in carrying out the program that has been planned in the academic process for evaluation purposes. It's detailed the budget for the need to improve the quality of education for the purpose of implementing all forms of academic process activities. The implementation of all work programs that have been arranged according to the time schedule in the semester time period, arrange the details of the needs in implementing the program that has been planned in the academic process for evaluation purposes. Supervision activities include each academic community that has been determined to provide reports on the progress of program activities that have been carried out in each part of the academic work program that has been announced in the planning.
\end{abstract}

Keywords: model; management quality; islamic higher education

\section{Introduction}

Based on its history, Islamic education has had many dynamic developments that have occurred from time to time, the point is that the educational process occurs with the aim of forming a whole Muslim person. The formation process is carried out by developing all human potential and fostering a harmonious relationship between each human person and Allah, humans, and the universe. Daulay (2019). The level of education in higher education is the path of formal education that is the highest; in this university a generation that is ready to make changes in society with their various professions is born. Therefore, the higher the quality of a university better the generation was born. So in this case, the interest of young people is also more interested in entering quality tertiary institutions. Regarding this, it can be seen that the community's enthusiasm for participating in the admission of new students at various high-quality and quality universities. Efforts to improve the quality of education have now become a commitment of the government to all Indonesians, namely by improving the quality of education. Anwar: (2018). Therefore, higher education institutions must also see and pay attention to the quality of education provided to students. Improving the quality of education is a strategic choice when it is associated with the increasing demands for competition in all fields at national and global coverage.

Management of improving the quality of education is a series of interrelated processes for collecting, analyzing, and reporting education quality data, educational programs, and educational institutions, therefore quality management leads to quality improvement. The quality assurance process covers areas to be achieved along with priorities development, presenting evidence-based planning data and decision making and supporting a culture of continuous improvement. Based on the consistency, it is explained about the concept of education management in a law that is more specific to Higher Education, namely Law Number 12 of 2012 concerning Higher Education and is the basis for the government and the DPR to improve the quality of education. Likewise, Presidential Decree No. 12 concerning KKNI Qualifications, then there is also a Permendikbud regarding SPMI. Policies regarding the quality assurance management strategy of a tertiary institution are a reflection of external parties, especially students and prospective students 
(Siram: 2015). Understand that the quality of education is very important and various opinions from experts and laws and regulations always prioritize the quality of education. The quality of education in an educational institution is expected to improve the quality of the nation which is equal to developed countries in various parts of the world. Based on the explanation above, the leadership of higher education is the main key in higher education quality. Therefore, the main role of higher education leaders is to work by making strategic programs. Mustah (2016), these strategic programs drive transformation and make educational institution programs have world-class quality excellence.

According to Husni \& Dafik's research (2018), Islamic higher education management in the 4.0 era requires adequate skills, considering that this era is an era of totality playing an important digital role. Another study, Mulyono \& Wekke (2018), academic culture and development of management strategies in the world of Islamic higher education is growing quite rapidly in line with advances in information technology, it is necessary to have skills in managing academic culture comprehensively. In line with Ilyasin (2017); Khairiah \& Sirajuddin (2019); Rafik \& Priyono (2018), Subandi (2020) and Asfiati, \& Wekke (2019) that improving the quality of Islamic higher education services is quite important to be carried out immediately in order to compete with public universities. In addition, Suryanto \& Patimah (2019) financial management in Islamic higher education also needs to be careful so that the utilization is right on target so that progress can be obtained. Several other studies, for example Asnawi \& Setyaningsih (2020), Qomari (2016), Junaidah et al (2020), Kafid \& Rohmatika (2020), Munadi \& Ernawati (2018), Nurzannah et al (2020), Abidin (2015), Qomari (2016), Kinoshita (2009) that the independence of Islamic higher education will be a milestone for the advancement of the world of education in Indonesia, many parties need to be involved in this. Comprehensive management is the main pillar to achieve independence and progress in all matters, including the role of alumni and related stakeholders.

Constitutionally, tertiary institutions as education must have various implementation guidelines, including regarding the organizational structure (Article 52 of Law No. 19 of 2005). In order to maintain the quality of implementation and product quality, the organization, work procedures of the institution, and procedures for quality assurance of education are regulated (KepMendiknas No 087/0/2003). With various regulations, it is hoped that the community can oversee the implementation of education that meets certain quality standards where graduates can compete.

In the province of North Sumatera, there are 42 private Islamic universities, three state Islamic universities, namely STAIN Madina, IAIN Padang Sidempuan, and UIN North Sumatra Medan. Of course, the existence of these state universities has an impact on other private universities, meaning that if the private universities are not qualified, the prospective students will be less interested in these universities. This also happened to STIT Al Hikmah Tebing Tinggi which is not far from the capital city of North Sumatra, besides UIN North Sumatra, other private universities have also become superior universities including UMSU, UISU, and others. For the last three years, STIT Al Hikmah has been led by Dr. Ficki Padli Pardede, MA, under his leadership STIT Al Hikmah underwent changes including the birth of two new study programs, namely Tadris Mathematics and PIAUD, and currently waiting for a visitation from the government to change its status to an institute. Lecturers who teach have also met the standards and 5 of them are continuing their doctoral education. The number of STIT Al Hikmah Tebing Tinggi students for 2019-2020 is 583 people with the following details:

a) PAI students: 246 people

b) PGMI students: 297 people

c) PIAUD students: 40 people

Based on this description, as a private university in Tebing Tinggi, it has attracted student enthusiasts from various regions. This is because the campus accreditations from several study programs have obtained $\mathrm{B}$ and one $\mathrm{C}$ accreditation. Even the Tebing Tinggi and Serdang Berdagai governments have collaborated in various fields, as well as cooperation with other universities in North Sumatera. The realization of quality at STIT Al Hikmah Tebing Tinggi is integrated with the vision, namely Islamic universities that are superior and competitive at the regional and national levels in developing Islamic disciplines and akhlakul karimah based education in 2030. Based on these considerations, research on quality improvement management becomes an affirmation in this research. This consideration is because without good management, quality is not achieved.

\section{Methods}

This study examines the quality improvement management of Islamic universities by examining STIT Al Hikmah Tebing Tinggi. Based on this, this study uses a qualitative method with a phenomenological approach, basically, this approach is interpretive because the research data is more concerned with the interpretation of the data found in the field (Sugiyono: 2014, 8). This approach is needed to understand the 
effectiveness of a program with the results achieved, namely the final benefits of a quality improvement management effort at STIT Al Hikmah Tebing Tinggi. The research used in this research can be designed to contribute to theory, practice, policy, social problems, and action. Therefore, this research is explored and deepened from a social phenomenon or a social environment consisting of actors, events, places, and times. Satori (2014). Based on the explanation above, this study aims to describe the empirical reality according to the phenomenon in detail and thoroughly, as well as to reveal the symptoms holistically contextually through data collection from natural settings by utilizing the researcher as a key instrument.

The main data sources in qualitative research are words or actions and documents that support the policy, the rest are additional data such as documents and others. Research informants are subjects who are required to obtain information in uncovering the necessary phenomena. In this case, the informants in question are the entire academic community of STIT Al Hikmah Tebing Tinggi. In this study, researchers used several data collection techniques commonly used in qualitative research, namely documentation, observation, interviews.

After the required data is collected and deemed sufficient, the next activity is to analyze the data. The analysis technique used in this research is qualitative-descriptive data analysis techniques and reflective analysis, namely analysis that is guided by a way of thinking which is a combination of induction and deduction thinking, as well as to answer the how and what questions. The descriptive data analysis technique is by collecting data related to the problem under study, then describing it so that it can provide clarity on reality or reality. While the analysis is to make details of the problem under study by sorting between one meaning and another, in order to obtain clarity on the problem under study.

\section{Results and Discussions}

\subsection{Overview of the STIT Al Hikmah Tebing Tinggi}

Tarbiyah College of Science (STIT) Al-Hikmah Tebing Tinggi is one of 42 PTKIS in North Sumatera under the supervision of Kopertais Region IX North Sumatra. STIT Al-Hikmah Tebing Tinggi is the development of the Al-Hikmah Medan Islamic College (STAI) which was officially changed in 2004. STIT Al-Hikmah Tebing Tinggi was founded on Saturday, November 19, 2004, spearheaded by Ir. H. Marapinta Harahap, M.AP, MM as the head of the Foundation, Drs. Zainuddin Siregar, SH, SE, MM, as Chairman of BPH, DRS. Masdar Limbong, M.Pd as secretary of BPH. Salman Rasidi MA as Chairman of STIT Al-Hikmah Tebing Tinggi. STIT Al Hikmah Tebing Tinggi focuses on cadre students to become professional educators. In accordance with what is written on the notary certificate, STIT Al Hikmah is under the Al Hikmah Islamic College Foundation (YASPETIA) which currently manages 4 (four) study programs, namely the Islamic Religious Education Study Program (PAI), the Madrasah Ibtidaiyah Teacher Education Study Program ( PGMI) and Early Childhood Islamic Education (PIAUD) and Mathematics Education / Tadris (TMM). Since the establishment of STIT Al-Hikmah Tebing Tinggi, the leadership at STIT Al-Hikmah Tebing Tinggi has changed leadership positions 3 times. The first period of the STIT Chair was Salman Rasidi MA, 2004-2014. Then after Salman Rasidi, MA passed away, the leadership of the STIT Chair was held by Drs. Zulfahri, MA from 2014-2018, but in 2016-2017 Drs. Zulfahri Inactive and Drs. Masdar Limbong, M.Pd was appointed as PLT Chairman at that time. In 2018 there was another change in leadership regeneration for the younger ones, at that time the chairman of STIT was held by Dr. Ficki Padli Pardede, MA.

\subsection{Quality Improvement Management at STIT Al Hikmah Tebing Tinggi}

Talking about quality improvement, it cannot be separated from the academic implementation process with graduates who are able to compete with outsiders. Likewise, STIT Al Hikmah Tebing Tinggi has made various efforts to improve the quality of higher education. Based on the results of observations, it was found that the facilities and infrastructure were able to accommodate all students without facing our own enemies. The concept of quality developed at STIT Al Hikmah Tebing Tinggi is based on knowledge and morals integrated in the Vision and Mission of STIT Al Hikmah Tebing Tinggi. based on this, the main concept in improving quality at STIT Al Hikmah Tebing Tinggi is to maintain control over spiritual values, honesty values, and tolerance values (Pardede: 2021, ii). To carry out this management, lecturers, students, and the entire academic community of STIT Al Hikmah Tebing Tinggi are involved in the academic service.

\section{Planning for Quality Improvement of Islamic Higher Education}

To improve the quality of Islamic higher education, of course, good campus management is needed, talking about management or management is certainly inseparable from the management functions themselves. Planning to improve the quality of Islamic higher education is carried out by compiling a framework in the fields of education, research, and community service. These three things are very important in higher education because they construct students to be ready as agents of change. In the field of education, 
planning includes how to achieve the maximum learning process in accordance with the predetermined curriculum. So in this case it involves the entire academic community of STIT Al Hikmah Tebing Tinggi. One of the uniqueness in improving the quality of Islamic higher education at STIT Al Hikmah Tebing Tinggi is its emphasis on knowledge and morals in every program that will be implemented. So that the final result of the student academic process is to become students who are knowledgeable and have good character with the values of Islamic education. So, the values of moral education emphasize all subjects taught in each study program, even though the teaching is in the context of scientific studies and how to teach students in tertiary institutions, likewise in the academic process that these values are integrated into academics. Therefore, in planning to improve the quality of Islamic higher education, it integrates the values of Islamic education in every program planning process in the tri dharma of higher education.

This verse gives the meaning that in order to reach someone, it is necessary to have education so that Islamic teachings and practice them. So, Islamic higher education, especially in its management, leads students to the religion of Allah Almighty, of course in doing role of good management is needed to form a quality institution. This concept is the basis for planning to improve the quality of Islamic higher education at STIT Al Hikmah Tebing Tinggi. The point is to make Islamic tertiary institutions into quality institutions; a mature plan is drawn up with the entire academic community. The goal is to form the uniqueness of the college so that alumni from STIT Al Hikmah have different uniqueness from others. of the. This is because the role of the campus environment, both in the learning process or in academic activities, has a very positive impact on students. If the entire academic community is built with a quality container, it will form a moral climate as well, and then it cannot be denied that there will be a civilization of Islamic higher education.

Based on integrated academic planning with various activities because the Tri Dharma College is an academic activity, the academic process that runs at STIT Al Hikmah is cooperative with other work units related to the purpose of STIT Al-Hikmah Tebing Tinggi. This is because in the planning led by the chairman of STIT Al Hikmah Tebing Tinggi the entire academic community. So in its implementation without good cooperation, the vision and mission of the tertiary institution will be constrained, while in management from planning to evaluation it will be carried out if it involves all elements in the organization. Thus, in planning the implementation of the three-pillar structural colleges and lecturers must have competence in carrying out duties and comply with operational standards, work procedures and be oriented towards efforts to improve work quality based on the provisions in the 2003 Lecturer and Teacher Law. education positions its role as an important part of STIT Al Hik This is the quality improvement in quality management at STIT Al Hikmah Tebing Tinggi mah Tebing Tinggi, while both the conceptualization and implementation of the program remain based on the rules in Islamic values as a characteristic of Islamic education, this is what is the quality improvement in quality management at STIT Al Hikmah Tebing Tinggi.

\section{Implementation of Quality Improvement}

The emphasis on the implementation of quality improvement at STIT Al Hikmah Tebing Tinggi is an implementation of programmed planning which includes high tridarma abortion. Based on this, the entire academic community of STIT Al Hikmah Tebing Tinggi collaborates in building quality activities by making standard rules with the aim of creating a quality culture. The formation of the quality of Islamic higher education is certainly inseparable from the quality culture that has been built in the educational institution itself. So in this case, the chairman of STIT Al Hikmah Tebing Tinggi as managerial has an important role in realizing the vision that has been set. So in this case, the implementation of quality improvement activities is grouped into two parts, namely the quality realized from the development of the vision and mission of STIT Al Hikmah Tebing Tinggi. The planning of the tridarma of higher education which is planned every year, and the program of the chairman once every four years. Based on this, the quality at STIT Al Hikmah Tebing Tinggi is the realization of the planned program that will give birth to cadres of STIT Al Hikmah graduates who are smart, innovative, sensitive to the surrounding conditions, creative in finding solutions to every nation's problems.

The explanation above can be seen from graduates who have taken part in various agencies, both government and private. For the last three years, the alumni of STIT Al Hikmah Tebing Tinggi have continued their education to the next level both in North Sumatra and outside North Sumatra. This proves that STIT Al Hikmah Tebing Tinggi graduates are taken into account in various government and private lines. From a social perspective, the achievement of these goals will provide satisfaction for alumni in particular and society in general. If the service received exceeds the expectations of the community, it is perceived as ideal service quality. To achieve this goal, it involves an academic process that focuses on improving the quality of education at STIT Al Hikmah Tebing Tinggi. The realization of this has taken several steps, namely: 
1. Details of the budget needed to improve the quality of education in the implementation of all forms of academic process activities

2. Implementation of all work programs that have been compiled in accordance with the time schedule that has been compiled in the semester time period.

3. Arrange the details of the needs in implementing the program that has been planned in the academic process for evaluation purposes.

\section{Supervision of Higher Education Quality Improvement at STIT Al Hikmah Tebing Tinggi}

For the implementation of programs that have been planned, it is necessary to monitor the implementation of the program. This is because the target that becomes the application is the academic process which includes the tri dharma of higher education in order to form students who already have cognitive maturity and experience a period of identity. This is because the concept of quality that is the emphasis at STIT Al Hikmah Tebing Tinggi is the mastery of science and its practice based on values in education. Efforts made by STIT Al Hikmah Tebing Tinggi to develop quality campuses in order to obtain information applied on campus to support campus programs. Based on this, it can be understood that the supervision carried out in improving the quality of education at STIT Al Hiikmah Tebing Tinggi is by making standard rules so that the movement of the academic community can be controlled.

Based on the foregoing, STIT Al Hikmah Tebing Tinggi takes steps to see the achievement of quality higher education. Based on the explanation above, it can be concluded that the supervision carried out in improving the quality of higher education at STIT Al Hikmah Tebing Tinggi is as follows:

1. Each academic community that has been determined provides a report on the progress of the program activities that have been carried out in each part of the academic work program that has been announced in the planning.

2. Reporting on the progress of the use of the budget for each section in the implementation of the academic process program.

3. In connection with lecturers and education staff, routine supervision is carried out in everyday life with the key to measuring the code of ethics that has been standardized by STIT Al Hikmah Tebing Tinggi.

4. For students, regular supervision is carried out in the daily learning and academic processes with the key to measuring discipline and obeying predetermined rules

\section{Evaluation in Improving the Quality of Education at STIT Al Hikmah Tebing Tinggi}

To find out the results of the programs that has been planned as well as how the supporting and hindering factors in the implementation of the planned programs. In this case, it is very important to do an evaluation. Every plan carried out by everyone will certainly see the results; this is what is meant by evaluation because every result is certainly not independent of evaluation. Based on this explanation, every attempt is made to find the right model. So that the concepts that have been determined in building through planning can run effectively, of course, involving various aspects, in this case with a variety of resources that are owned and adequate in the field of scientific development, the whole becomes the work of evaluation (Ismail: 2002,78).

Based on this explanation, the concept of quality cannot be separated from three things, namely covering all processes (every process), covering every job (every job), and covering everyone (every person) which is then called the term integrated quality. Customers, in education, called students, will be an assessor of quality and the institution itself, this means that the institution or institution will not be able to survive if they are not there (Syafaruddin: 2002, 78). The evaluation process carried out at STIT Al Hikmah in the implementation of programs that have been determined whether the implementation of learning, academic activities, vision, and mission is a realization of improving the quality of education itself. Evaluation activities are carried out every week, not semiannually or annually, the goal is that every obstacle and the running of the program is evaluated every week. So the solution you get as you go along means being immediately implemented. Meanwhile, to revise programs that are constrained or if there is a program being developed, it is carried out at the end of each semester. Based on this explanation, it is clear that the evaluation is carried out by STIT Al Hikmah Tebing Tinggi on a weekly basis, while to legalize each solution to the problem it is carried out every semester either to revise the program or to develop the program so that the program carried out always develops according to the needs of students and the use of graduates. The implementation of the evaluation developed at STIT Al Hikmah uses the concept of freedom by providing opportunities for the entire academic community to evaluate ongoing programs. Based on this, it can be seen that the evaluation attitude at STIT Al Himah Tebing Tinggi is as follows:

a. Process that runs continuously

b. Filled with the concept slowly

c. The changes made carry the mission of rahmatal lil 'alamin.

d. Every regulation that is carried out is resolved by way of deliberation. 


\section{Conclusion}

Based on the explanation above regarding the quality management of Islamic higher education at the STIT Al Hikmah Tebing Tinggi, it can be concluded that planning activities include activities of higher education tri dharma programs both developing vision and mission or programs carried out based on evaluation results. Meanwhile, the implementation activities include detailing the budget needed to improve the quality of education in the implementation of all forms of academic process activities. Then the implementation of all work programs that have been arranged according to the time schedule in the semester time period, compile the details of the needs in carrying out the program that has been planned in the academic process for evaluation purposes. The author details the budget for the need to improve the quality of education in the context of implementing all forms of academic process activities. The implementation of all work programs that have been prepared in accordance with the time schedule that has been prepared in the semester time period, arrange the details of the needs in implementing the program that has been planned in the academic process for evaluation purposes. Supervision activities include each academic community that has been determined to provide reports on the progress of program activities that have been carried out in each part of the academic work program that has been announced in the planning. The reporting of the progress of the use of the budget for each section is used for the implementation of the academic process program. In connection with lecturers and education staff, routine supervision is carried out in everyday life with the key to measuring the code of ethics that has been standardized by STIT Al Hikmah Tebing Tinggi. For students, regular supervision is carried out in the daily learning process and academics with the key to measuring discipline and obeying predetermined rules. Evaluation activities include a continuous process, characterized by the concept of land, changes made to the mission of rahmatal lil 'alamin, every regulation carried out is completed by deliberation.

\section{Acknowledgement}

The authors would like to thanks to the people who have been instrumental in their assistance and the successful completion of this study.

\section{Author's Contribution}

All authors discussed the result and contributed to from the start to final manuscript.

\section{Conflict of Interest}

The authors declare that they have no competing interests.

\section{References}

Abdullah, M. A. (2017). Islamic studies in higher education in Indonesia: Challenges, impact and prospects for the world community. Al-Jami'ah: Journal of Islamic Studies, 55(2), 391-426.

Abidin, M. (2015). Students' perception of service quality dimensions in Islamic higher education. International Journal of Innovative Research \& Development, 4(1), 237-242.

Asfiati, A., \& Wekke, I. S. (2019). Lecturers' participation in applying blended learning in Islamic higher education in Indonesia. Universal Journal of Educational Research, 7(12), 2604-2608.

Anintya, Y., A. (2016). Analisis Kemampuan Komunikasi Matematis Ditinjau Dari Gaya Belajar Siswa Kelas VIII Pada Model Pembelajaran Reseource Based Learning. Skripsi. Universitas Negeri Semarang.

Anwar, K. (2018) "The Role of the Education Quality Assurance System in Improving the Quality of Education in Madrasas," in Ta'dibuna: Journal of Islamic Religious Education, Vol. 1, No. 1, 2018

Asnawi, N., \& Setyaningsih, N. D. (2020). Perceived service quality in Indonesian Islamic higher education context: A test of Islamic higher education service quality (i-HESQUAL) model. Journal of International Education in Business.

Daulay, H., P. (2019), Islamic education in Indonesia historically and its existence, Jakarta: Pranadamedia

Husni, H., \& Dafik, Y. F. (2018). Management of Islamic Higher Education in the 4.0 Industrial Revolution. Educational Review: International Journal, 15(2).

Hambali, M., \& Idris, I. (2020). Transformational leadership, organizational culture, quality assurance, and organizational performance: Case study in Islamic Higher Education Institutions (IHEIS). Jurnal Aplikasi Manajemen, 18(3), 572-587.

Ilyasin, M. (2017). Balanced Scorecard: A Strategy for the Quality Improvement of Islamic Higher Education. Dinamika Ilmu, 17(2), 223-236. 
Ismail, S. M. (2002), Development of Traditional Pesantren, a Hypothesis Anticipating Social Change, Yogyakarta: Pustaka Belajar.

Junaidah, J., Basyar, S., Pahrudin, A., \& Fauzan, A. (2020). Strategic Management Roadmap: Formulation, Implementation, and Evaluation to Develop Islamic Higher Education Institution. Tadris: Jurnal Keguruan dan Ilmu Tarbiyah, 5(2), 335-347.

Kafid, N., \& Rohmatika, A. (2020). Academic social capital and institutional transformation of Islamic higher education in Indonesia. Akademika: Jurnal Pemikiran Islam, 24(2), 335-352.

Khairiah, K., \& Sirajuddin, S. (2019). The Effects of University Leadership Management: Efforts to Improve the Education Quality of State Institute for Islamic Studies (IAIN) of Bengkulu. Jurnal Pendidikan Islam Yogyakarta, 7, 239-266.

Kholid, A., \& Purba, A. S. (2021). Improving the Competitiveness of Islamic Higher Education: Study Approaches to Development of Human Resource Competencies (HR). Review of International Geographical Education Online, 11(3), 477-493.

Kinoshita, H. (2009). Islamic higher education in contemporary Indonesia: Through the Islamic intellectuals of alAzharite alumni. Kyoto Working Papers on Area Studies: G-COE Series, 81, 1-27.

Mulyono, M., \& Wekke, I. S. (2018, July). Academic and Culture Development Strategy Management for Islamic Higher Education In Indonesian. In IOP Conference Series: Earth and Environmental Science (Vol. 175, No. 1, p. 012163). IOP Publishing.

Munadi, M., \& Ernawati, F. (2018). The Reality of Knowledge Management in Islamic Higher Education. Jurnal Pendidikan Islam, 7(2), 225-237.

Nurzannah, N., Ginting, N., \& Setiawan, H. R. (2020, January). Implementation Of Integrated Quality Management In The Islamic Education System. In Proceeding International Seminar of Islamic Studies (Vol. 1, No. 1, pp. 1-9).

Mustah, J. (2016) Education Policy Analysis, Jakarta: Pranadamedia.

Pardede, Ficki Padli, (2021), Implementation of Moral Education Values at STIT Al Hikmah Tebing Tinggi (Dissertation: UIN North Sumatra).

Qomari, R. (2016). The Evaluation of Curriculum Implementation on Islamic Higher Education in Indonesia. Ijtimā'iyya: Journal of Muslim Society Research, 1(1), 97-112.

Rafik, A., \& Priyono, A. (2018). A new insight into alumni satisfaction model for Islamic higher education institutions (IHEI). Management Research Review.

Satori, D. and Komariah, A. (2014) Qualitative Research Methodology, cet. 6, Bandung: Alfabeta.

Siram, R. (2015), "Management of Quality Assurance for Higher Education Academic Services," in the Journal: Educational Sciences, Jild 21, Number 1, 2015

Sugiono, (2014), Educational Research Methods, Quantitative Approaches, Qualitative and R \& D, cet. 21, Bandung: Alfabeta.

Subandi, S. (2020). Quality Development Model of Management Islamic Religious Higher Education of Nahdltul Ulama. Jurnal Iqra': Kajian Ilmu Pendidikan, 5(2), 107-121.

Suryanto, T., \& Patimah, S. (2019). Strategy Analysis of Financing Management Quality toward Performance Improvement of Islamic Higher Education in Lampung. Journal of Education, Teaching and Learning, 4(2), 321-325.

Syafruddin, (2002), Integrated Quality Management; Concepts, Strategies, and Applications, Jakarta: Youth Rosdakarya 